\title{
Epigenetic Regulation: Neurite Outgrowth by Hormonal or Chemical Mechanisms in PC12 Cells
}

\section{Koji Shimoke*}

High Technology Research Core (HRC), Department of Life Science and Biotechnology, Faculty of Chemistry, Materials and Bioengineering, Kansai University, Yamatecho, Suita, Osaka, Japan

"Corresponding author: Koji Shimoke, High Technology Research Core (HRC), Department of Life Science and Biotechnology, Faculty of Chemistry, Materials and Bioengineering, Kansai University, Yamate-cho, Suita, Osaka 564-8680, Japan, Tel: +81-6-6368-0853, +81-6-6330-3770; E-mail: shimoke@kansai-u.ac.jp

Received date: December 27, 2016; Accepted date: December 29, 2016; Published date: December 31, 2016

Copyright: $\odot 2016$ Shimoke K. This is an open-access article distributed under the terms of the Creative Commons Attribution License, which permits unrestricted use, distribution, and reproduction in any medium, provided the original author and source are credited.

\section{Editorial}

In the embryonic stage, cells divide and migrate to achieve differentiation. Neurite outgrowth is involved in forming precise neuronal networks in neuronal differentiation, and can be mimicked in vitro using specific reagents. For instance, nerve growth factor (NGF), which was identified by Levi-Montalcini and Booker, strongly promotes neurite outgrowth in cells from the peripheral nervous system (PNS) [1]. A similar effect is seen in pheochromocytoma 12 (PC12) cells, which were established by Greene and Tischler [2,3]. In the four decades since establishment of these cells, many hormones (including peptides) and chemicals have been shown to promote neurite outgrowth in PC12 cells [4,5]. Surprisingly, epidermal growth factor (EGF), which is associated with cell division, promotes neurite outgrowth through a specific intracellular mechanism [4]. cAMP, an activator of intracellular protein kinase A (PKA), has also been reported to promote neurite outgrowth [5]. Evidence for a role of the nur77 gene in neurite outgrowth has been found, and the mechanism involves epigenetically regulated gene expression because it is influenced by trichostatin A, a histone deacetylase (HDAC) inhibitor that changes heterochromatin to euchromatin and has a similar effect to that of histone acetyl transferase (HAT)-induced gene expression in a specific region of the genome [5,6]. Generally, methylation of lysine 9 or 27 in histone $\mathrm{H} 3$ suppresses gene expression in association with chromodomain-containing negative transcriptional regulators, and methylation on lysine 4 induces gene expression. These epigenetic phenomena also depend on lysine acetylation in histone H3. Our study of neurite outgrowth in PC12 cells showed the importance of acetylation of lysine 14 in histone $\mathrm{H} 3$ in this process [6]. However, the role of demethylation of $\mathrm{CpG}$ sequences in the upstream sequence of the nur77 gene was unclear. Moreover, modification of histone $\mathrm{H} 4$ also requires analysis to develop a complete understanding of the mechanism of neurite outgrowth. These findings may just represent an initial understanding of epigenetic mechanisms in this field.

\section{Research Support}

KAKENHI(16K00626), SENRYAKU(2013-2017).

\section{References}

1. Levi-Montalcini R, Booker B (1960) Excessive growth of the sympathetic ganglia evoked by a protein isolated from the mouse salivary glands. Proc Natl Acad Sci USA 46: 373-384.

2. Greene LA, Tischler AS (1976) Establishment of a noradrenergic clonal line of rat adrenal pheochromocytoma cells which respond to nerve growth factor. Proc Natl Acad Sci USA 73: 2424-2428.

3. Tischler AS, Greene LA (1978) Morphologic and cytochemical properties of a clonal line of rat adrenal pheochromocytoma cells which respond to nerve growth factor. Lab Invest 39: 77-89.

4. Yamada M, Ikeuchi T, Aimoto S, Hatanaka H (1996) PC12h-R cell, a subclone of PC12 cells, shows EGF-induced neuronal differentiation and sustained signaling. J Neurosci Res 43: 355-364.

5. Maruoka H, Sasaya H, Shimamura Y, Nakatani Y, Shimoke K, et al. (2010) Dibutyryl-cAMP up-regulates nur77 expression via histone modification during neurite outgrowth in PC12 cells. J Biochem 148: 93-101.

6. Tomioka T, Maruoka H, Kawa H, Yamazoe R, Fujiki D, et al. (2014) The histone deacetylase inhibitor trichostatin A induces neurite outgrowth in PC12 cells via the epigenetically regulated expression of the nur77 gene. Neurosci Res 88: 39-48. 